\title{
Social determinants of a Quilombola Community and its interface with Health Promotion
}

\author{
Determinantes Sociais de uma comunidade quilombola e a interface com a Promoção da Saúde \\ Determinantes sociales de una comunidad quilombola \\ y la interfaz con la promoción de la salud
}

How to cite this article:

Durand MK, Heidemann ITSB. Social determinants of a Quilombola Community and its interface with Health Promotion. Rev Esc Enferm USP. 2019;53:e03451. DOI: http://dx.doi.org/10.1590/S1980-220X2018007703451

\author{
Michelle Kuntz Durand ${ }^{1,2}$ \\ Ivonete Teresinha Schülter Buss \\ Heideman ${ }^{1,3}$ \\ 1 Universidade Federal de Santa Catarina, \\ Programa de Pós-Graduação em \\ Enfermagem, Florianópolis SC, Brazil. \\ 2 Universidade Federal do Paraná, Departamento \\ de Enfermagem, Curitiba, PR, Brazil. \\ 3 Universidade Federal de Santa \\ Catarina, Departamento de Enfermagem, \\ Florianópolis, SC, Brazil.
}

\begin{abstract}
Objective: Understanding the relationship of social determinants in the Health Promotion of quilombola women. Method: This was a participatory study developed through the Research Itinerary of Paulo Freire, which comprises three stages: thematic investigation, codification and decoding, and critical unveiling. These stages were developed in Culture Circles from April to June 2016. Twenty themes were investigated, coded and decoded into eight themes, revealing the theme of women and their relationship with the Social Determinants. Results: Ten women from a quilombola community in Santa Catarina participated. The Health Promotion of this population and its interface with Social Determinants were understood. Health, religiosity, racial issues, social and community networks emerged as potentializing community empowerment and solidification. Conclusion: An accentuated correlation of racial issues and fragility combined with health care, education and information, and above all the distancing of vulnerable communities from comprehensive and equitable health was observed, highlighting the imminent need to strengthen Health Promotion strategies.
\end{abstract}

\section{DESCRIPTORS}

Social Determinants of Health; Health Promotion; Women; African Continental Ancestry Group; Personal Autonomy; Public Health Nursing.
Corresponding author: Michelle Kuntz Durand

Rua Nereu Ramos, 1441D/ apto. 601 - Centro CEP 89801-021 - Chapecó, SC, Brazil michakd@hotmail.com 


\section{INTRODUCTION}

Health Promotion aims to recognize the inspirations and needs of individuals so that it is possible to change the environment in which they transit and consequently reach a full state of individual and collective physical, mental, and social well-being, going beyond a healthy lifestyle, as it encompasses an overall well-being ${ }^{(1-2)}$.

The conception of Health Promotion, although contemporary, still prevails as a term with ambiguities and contradictions. This dichotomy is linked to the presence of two different discourses: one with an emphasis on modifying individual behaviors, and another that seeks to advance towards a liberating perspective by strengthening the population's participation in confronting social determinants ${ }^{(3)}$.

In Brazil, the Health Promotion Policy had a long and conflicting process until its promulgation in 2006, and its redefinition in 2014: it reinforced the fundamental values of solidarity, happiness, ethics, respect for diversity, humanization, responsibility, justice and social inclusion, and adopted the principles of equity, social participation, autonomy, empowerment, intersectoriality, intrasectoriality, sustainability, comprehensiveness and territoriality. This Policy highlights the Social Determinants of Health $(\mathrm{SDH})$ as a possibility to reduce inequities and promote equity in health ${ }^{(4)}$.

Integrating the two approaches of Health Promotion and Social Determinants of Health can contribute to understanding and challenging health disparities with a view to social well-being, since this integration focuses on the role of inequality reduction policy and distances itself from traditional health discourse based on the individual ${ }^{(5)}$.

It is recognized that risk factors ${ }^{(6)}$ are not equally distributed among populations. Certain subgroups, particularly those with low socioeconomic status, have been found to have higher proportions of risk factors and consequently suffer from precarious health.

Communities with social vulnerability are inserted in this context; a concept that refers to the capacity to struggle and to the recovery of individuals and social groups to confront the health issue ${ }^{(7)}$. Social vulnerability implies in characteristics, resources and abilities inherent in the subjects or groups, which may be scarce or inadequate to take advantage of the opportunities available in society. Thus, this relationship will determine the degree of impact on individuals' quality of life ${ }^{(8)}$. In this way, the "quilombo remnant" population stands out as a vulnerable ethnic group, especially females, who face an environment of discrimination, prejudice and disrespect, constantly having to revindicate their rights and citizenship.

In order to conceptualize the theme in question, the word "quilombo" stands out because it has greater recognition and notoriety, since the term is based on Bantu etymology, which means "warrior camp in the forest". It was popularized in Brazil to support organizations instituted by insurgents against the slavery regime and its resistances, vindications and battles against slavery; this expression also brought forth a relevant interpretation for the liberated in their journey, struggle and independence, conquering other contexts and perspectives ${ }^{(9)}$.

Quilombola communities are marked by historical processes of discrimination and exclusion, and experience a marginalized socioeconomic reality in relation to the Brazilian population in general ${ }^{(10)}$. Thus, it is fundamental to combine studies of Social Determinants to Health Promotion, especially of socially vulnerable populations.

In this sense, we seek to perform a work with a group of quilombola women due to their organization and leadership within a scenario of struggling to overcome social inequities, in order to understand the relationship of Social Determinants in Health Promotion of these women.

\section{METHOD}

\section{STUDY TYPE}

This is a qualitative, action-participant research study. The Research Itinerary of Paulo Freire was used as a methodological reference, which consists of three intertwined dialectical moments: thematic investigation, codification and decoding, and critical unveiling ${ }^{(11-13)}$, developed in Culture Circles.

The Culture Circle was named by Freire and represents a dynamic moment of dialogue and knowledge; it is an open space which enables different exchanges, mutual respect and the construction of distinct knowledge. Everyone advances through the process of action-reflection-action and "exits" different from how they enter, as limiting situations of reality are revealed and they reflect on it, and then they decode it and visualize it ${ }^{(13,14)}$.

In addition, Paulo Freire's Research Itinerary scheme is demonstrated by colors on a moving wheel, as shown in Figure 1, below. The symbolism of a rose is represented in the Thematic Research refers to the ingenuity during the course of the study in generating themes. The codification lilacs, still in a moment of magic, transitioning to gray to represent the exercise of decoding, where the exercise of a critical and reflexive look unfolds. The green in the Critical Unveiling symbolizes the freedom of thought provided by the dialogical encounters culminating in awareness, as represented by the yellow in remitting to light and knowledge. It is also perceived that red transits as a symbol of energy, passion and provocation within the circle, representing the constant dialogical problematizations provided by the encounters and linked with the continuous process of action-reflection-action.

The Culture Circles took place in the Quilombola Community called Morro do Fortunato, municipality of Garopaba, Santa Catarina state. The Community is located in a rural area, with difficult access both to health services and basic human needs. This community was elected by approaching the state's quilombola communities and conversing with their leaders, who indicated it as a positive and representative population, with strong receptivity and acceptance of ethnic and racial studies and research. 


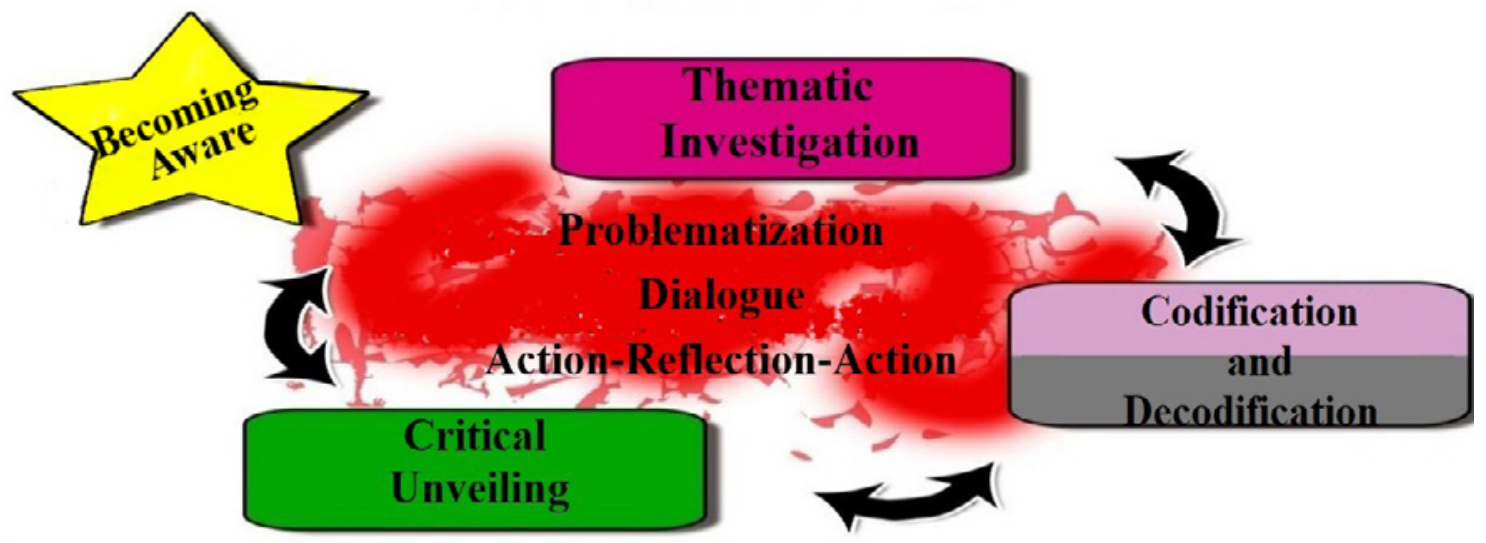

Figure 1 - Research Itinerary scheme represented in Colors.

The Culture Circles had the participation of 10 quilombola women aged between 24 and 54 years old, living in the Morro do Fortunato Quilombola Community. Women who resided in other adjacent quilombola communities were not included in this study.

The thematic investigation occurred over the course of six Culture Circle meetings from April to June 2016. The Research Itinerary stages were carried out during these three months. The meetings took place with the "women's group", held weekly at the Association's Headquarters in which the women of the Community have been meeting for 8 years. It was agreed that the meetings related to the research would be on the days of the women's group.

The participants were introduced in the first meeting, as well as the proposal and the study objectives along with an explanation of the study methodology to be developed in the Culture Circles.

In the second meeting we needed to reconfirm and plan the dates and times of the meetings, for which we agreed would be 2 hours before the manual work of the participants. The group reception and their interest in the study were already observed on this day. We also completed the individual socioeconomic questionnaire in this initial phase with the objective of getting to know them and understand their way of thinking about quilombola health and living.

The third meeting was the moment in which we began a survey for generating themes. An activity of clipping and collage of journals was proposed, based on the Social Determinants of Health and related to quilombola living.

In the fourth encounter we experienced the second phase of the Culture Circle (codification and decoding), in which the 20 themes generated by the women in the Thematic Investigation were selected, which were then inserted onto cards and discussed with the group, requesting that each one choose the one which interested them the most.

After selecting the women's cards of interest, the generating themes were reduced to eight, which were then worked on in two different groups. The proposal was that each group of participants mediated by the researcher and/or the research assistant would discuss the selected themes so that these were later decoded in a large group.
It is noteworthy that in the decoding phase it was necessary to deepen two of the generated themes, which were decoded as transversal to the others: health themes and quilombola women. Topics that lacked further reflection and discussion were decoded in the fifth meeting, which led to the unveiling.

Critical Unveiling took place in the sixth meeting, in which two significant themes related to the Social Determinants of quilombola women and access to health were unveiled.

This study was conducted in a linear and participative way; therefore, it was possible to explore the different participations of each member and to value the richness in loco, mutual care and the various ways of learning and apprehension. Thus, the importance of being open to the new and diverse ways of thinking and building health was ratified.

The themes were recorded in a field notebook, where the observations and information learned during the experiences with the participants were inserted. Audio recorders were also used after consent was given by the participants, and the recorded themes were reproduced by the researcher through directed transcription.

\section{ETHICAL ASPECTS}

This study was evaluated and approved by the Quilombola community and by the Human Research Ethics Committee of the Federal University of Santa Catarina under Opinion No. 1.466.641 in 2016, pursuant to Resolution 466/2012 of the National Health Council, respecting the ethical principles of autonomy, beneficence, non-maleficence and justice. The anonymity of the participants (named by codenames chosen by themselves) was respected, and their participation in the study was authorized by signing the Free and Informed Consent Form.

\section{RESULTS}

Ten women aged between 24 and 54 years belonging to the Morro do Fortunato community participated in this study. In relation to schooling, only one did not study, five finished elementary school and four had completed high school (one is ending this year). Eight of the women have children: two have one son, two have two children, three 
have three children and one of the women has four children. Regarding their professions, one is a clerk, three of the women are vendors, one is a general service assistant, one is an artisan and four are stay-at-home mothers. Regarding their residence time in the Morro do Fortunato, five have always lived there. The shortest residence time was six months, and the longest time was 26 years.

Twenty raised themes were generated over the course of the Culture Circles, subsequently codified and decoded into eight of interest for the group, and further reduced to four which are discussed below.

\section{Social Determinants and the Health of Quilombola WOMEN}

The concept of Health Promotion linked to Social Determinants allows us to have an expanded view of living well, which brings us to the extension of what is thought and proposed in health.

Thus, new reflections were proposed in the course of the Culture Circle meetings regarding the concept of health connected only to the absence of disease and/or health systems, as in Morgana's speech which refers to care only being centered on the professional figure:

The Community Health Agent came here only once during my entire pregnancy. It was a risky pregnancy. I lost my baby, and the Agent only came here once, and made a file. This is something that I don't see here (Morgana).

Or still, when viewing a photo of a man in a white apron, they quickly report:

Another health photo here ... a doctor ... (Querida).

Health centered on the figure of the health professional refers to a still naive, biomedical view, and a reduced view of its expanded concept. Some provocations were produced, generating reflections and questions about health and the factors that promote it.

In decoding this theme, the group was asked about the concept of health, and the reflections began to become productive:

Health for me is living well. Health is everything! It's healthy eating. It is to live in peace, with much love for one another. Here in this smiling person! This is happiness and which I consider health. And family. Mother, father (...) (Cheirosa).

This was a crucial point revealed in the speeches and unveiled in the group, representing an expanded form of thinking and conceptualizing health, and relating it to Social Determinants. The relationship that the participants have with healthy lifestyles, happiness and well-being is perceived, having the family in harmony as a foundation.

\section{Social Determinants and the religiosity of QUILOMBOLA WOMEN}

Among the determinants that stood out strongly in the meetings was religiosity. On the sociodemographic questionnaire, $70 \%$ of the participants put the Catholic religion as their religious option, one (10\%) is Evangelican, one (10\%) is Wicca and Celtic, and one refers to following all religions.
Although the option for spiritualism was not revealed in the course of the discussions, closeness/similarities with this religious current emerged in the dialogue Circles.

A closeness between faith and being healthy was observed, describing the thinking as a strength for healing: One day I also had high blood pressure, but I thought, 'I don't accept that' (...). I took care with salt and food and put it on my head that I would not take medicine at all until I was well. I spent the whole week with only a little salt in my food, lots of salad, green leaves and I was good ... Take care of your food to see if you will need to take medicine ... And another thing, you have to believe that you will be well. After all, do you have faith or not? (Cheirosa).

The relationship of spirituality as a strategy for healing becomes even more evident in statements of blessings and other religious beliefs. Alternatives of complementary treatments were discussed in the Culture Circles, which are based on faith and belief as a treatment and cure:

There are some people here who still believe and you have to respect them. In the past there were those who participated in consultations with the "benzedeira". Since we did not have a doctor, the consultation was always with her. I don't know if they still have $i$, but there used to be more. She was wearing an outfit, she blessed me, she gave tea and cured a lot of people (Batalhadora).

When thinking about religion, one perceives a strong relation with care practices and ways of thinking about health, and reaches an instigating contemplation in facing the reality of the participants, in other words an understanding of being black and how much the religious differences influence their health issues, struggles and organization, moral issues/preconceptions, their living in community and the strengthening of quilombola communities, meaning that they experience a valuation of cultural issues and customs such as health and healing.

\section{Social Determinants and RaCe ISSUES OF QUILOMBOLA WOMEN}

Although often masked in everyday life, racist and segmented discourse is still present in the women's speeches when they tell about certain experiences. It is often camouflaged and perhaps linked to cultural practices, yet prejudice is perceived by subtle but recurrent euphemisms:

It comes from ancestors (...). Now we are not so reproached. But there are places we go and they look at us a little strange. Atleast employment is good (Amorosa).

The participants report that employment opportunity as "good", but in the course of the dialogues they verbalize, although still in a naive and unnoticed way, that color and race are often linked to underemployment, which for the most part do not require professional qualification and/or financial resources to enter the labor market. This is reported in the following speech:

For us this goes into the university. Even because I don't understand much why my profession is to be a cleaning lady and I can't leave it, but as it goes inside the university, for us it is pride, it is gratifying (Flor). 
The dialogue in the Culture Circles made it possible to reflect on the theme of racism. This theme begins to be unveiled and perceived in facing the barriers that they find in their routines, thus enabling a new way to perceive, and with that to be strengthened:

Racism also generates difficulty to access ... Even to get a better job, to leave illegal work. That's why they end up having jobs as a cleaning lady, or bricklayer. Husbands working without a formal labor contract. Her daughter, for example, started going to college, but it was in Tubarão (city) and it was very difficult, so she gave up. So all this is difficult access ... Even to have a better future (Flor).

The participants begin to perceive themselves as women strengthened by the adversities that the issue of race makes them experience. The discussions in the circles culminate with the unveiling of a very present issue in vulnerable populations, namely prejudice:

The difficulty of access and racism show how much we are warriors. Let's sidestep the difficulties and touch/experience life in a good mood (Flor).

The dialogue in the Circles stimulated reflection and articulation of the SDH on racial issues. Racism appears beyond discrimination, but it has a split between the issue of job opportunities, as well as access to health services. This theme comes to be seen as a form of strengthening based on resistance and social struggle in the history of the Morro do Fortunato quilombola community's constitution.

\section{Social Determinants of Health and Social and COMmunity Networks}

A potentiality unveiled in the course of this study refers to the structuring of social networks developed by the group. Although not yet recognized as an important characteristic linked to living in a community, the participants initially demonstrate that they do not consider themselves united and manifest this adjective as something inherent in the past, which is discussed in the Culture Circle meetings:

More so in the past. I think the elders were really united (Batalhadora). It's not so much anymore today. (Apaixonada). And Violeta added: It is everyone for themself (Violeta).

The participants highlighted the difficulty in communicating and complained they could feel more present and support themselves more because they were geographically close and all of them familiar with each other. They mentioned that daily activities are increasingly individual and become a reason for separation between them:

In the past everything was done together, from washing clothes in the fountain, doing everything together and communicating (Apaixonada).

A new reflection begins to emerge in the course of the debate, and with this they perceive a different way of characterizing themselves. They come to understand that relationships accompany temporal changes, and as a result they undergo changes that can be seen from a new perspective: Women today are overwhelmed. In the old days she did not have so much to do. Today she works at home and out. At that time she was washing clothes by day at the fountain and today she also spends the day working. How are you going to wash clothes at the fountain at night? (Apaixonada).

Although they perceive the increasing role of women in everyday spaces, there is still a gender inequality in the community. The transition from empowerment to an overload in the women's role is identified by these women as a still ambiguous achievement, which is revealed in the following lines:

We respect men (Cheirosa). And Violeta added: But who battles the most, in the fight here (...) are the women (Violeta).

The woman has to run back, sweating (...). There are somethings I do here which are for men and women. You do not have to wait for men (Apaixonada).

The reflections worked out in the meetings incite provocations to the reciprocity of the group and mutual affection between them. A new perception then emerges, allowing to overcome the alienation linked to comparing past experiences and enabling an analysis of the current reality and the astuteness in facing the dynamicity of life and its real strengths, as expressed in speech:

Really, girls. We have our faults, but we also have many qualities. I think we even have more quality than defects. And we are united (...) (Batalhadora).

The position of the studied women in the study on Social and Community Networks are directed to the past as a communication difficulty in the present time, as they find the temporal changes in the Culture Circles and their influence on the communication form, perceiving the union, differences and the inclusion that transits the group.

\section{DISCUSSION}

It is understood that as the dialogical process advances, new concerns and conceptions emerge, and so the issues are reflected and broadened by the participants. Therefore, the themes of health, religiousness, race and community relations discussed in this study need to be debated and defined with the perspective of being used with more coherence and understanding, contributing to improving the quality of life of the women studied in the community.

The concept of health transcendent to the absence of disease presents an expanded view and is linked to healthy habits, leisure and living in harmony, to religiosity, to happiness and to the family, perceives the individual in their singularity and in the real context in which they live. This concept is linked to health promotion ${ }^{(15)}$ and advances when influenced by movements to reduce social inequalities and inequities, contemplating prerequisites in its concept to actually achieve it.

Living with or without health is not limited to organic, natural and objective evidence, nor to a state of equilibrium, but it is strongly linked to the sociocultural characteristics and meanings that each subject attributes to their living process ${ }^{(15)}$.

Health is not only seen as absence of disease, it departs from the reductionist concept and focuses on the professional 
figure, enables discussions focused on the conception of expanded health-disease and its articulations with the living process ${ }^{(1)}$.

It has been reported that it is difficult for health professionals ${ }^{(16)}$, including nurses, to address all issues related to the health/disease process, and their interest in including other social, cultural and spiritual influences in care practices is necessary.

Investigating care directs the individual or the family to seek various possibilities related to their beliefs and/or spirituality in a real religious synergy. This spirituality is often found with a healer, "benzedeira" and/or other popular therapies, being the opposite of what is found in the traditional health system: a person with similar experience, who understands the needs of the patient with empathy ${ }^{(17)}$. Therefore, health must be seen beyond the biological perspective, also encompassing the conception of SDH as a foundation for well-being.

Therefore, it reinforces that religiosity and belief in alternative therapies have a relevant perspective in health care. By means of popular knowledge, the traditional health system is no longer seen as a segmented care practice, evolving towards an expanded understanding of the health and disease process, and acquiring an important meaning within the health-disease process in order to provide answers to what is inexplicable within the biomedical model of healthcare ${ }^{(18)}$.

The participants highlighted the relationship of color and race racism/prejudice with underemployment and difficulties of social insertion into society. Clarity is ratified along with research on social and racial-ethnic inequalities that permeate Brazilian society, since there is usually a great chasm that separates well-to-do groups from subalternized groups, especially historically stigmatized, oppressed and marginalized groups such as blacks and indigenous people, among others ${ }^{(19)}$.

Black Brazilians internalize their belonging to a social minority from an early age. This classification is exalted, while the opportunities are inserted as a minimum condition of survival linked to low levels of education as a factor of social and political exclusion, still being preponderant for conserving the status quo of Brazilian society, as pointed out by deep inequalities ${ }^{(20)}$.

Official history omits the protagonism and the insubmission of black women who, in facing the subordination, segregation and vulnerability, maintained resilient movements for maintaining and strengthening their culture ${ }^{(21)}$.

An empowered person or group is one who performs, by themself, changes and actions which lead them to evolve and grow stronger ${ }^{(22)}$. Emancipatory movements are articulated to the notion of self-esteem of social groups, mainly referring to their individual and psychological dimension ${ }^{(23)}$. It reinforces the imminent need for dialogical exchanges and an expansion of Health Promotion as a strategy for community empowerment.

The feminist empowerment practices studied in a literature review pondered the contexts in which women live and reflected on the reproductive and domestic role they occupy, emphasizing community living as a propulsion strategy and visibility to the feminine role ${ }^{(22)}$. Empowerment emerges as a powerful conception and evaluation of practices which promote female autonomy to overcome the inequality of power in which women, especially black women, find themselves.

Thus, it is necessary to highlight the need to foster strengthening of individual and collective capacities through the multiple Social Determinants, which condition and promote health and well-being ${ }^{(23)}$.

\section{CONCLUSION}

The development of this study sought to understand the relationship of Social Determinants and Health Promotion of this socially vulnerable community, having the experience in the meetings with the quilombola women's group as a guiding factor.

We highlight the Social Determinants of Health related to employment, living and working conditions, religiosity, family, social networks, customs, female empowerment, racism and access to health services. The concept of health was comprehensively and holistically debated, making it possible to articulate it with social, psychological, political, racial, cultural and historical issues, reinforcing its expanded concept, and not merely the absence of diseases.

There is a strong perceived correlation between race relations and fragility combined with care, education, health information, and above all distancing of vulnerable communities from reaching comprehensiveness and equity, highlighting the imminent need to promote practical strategies of health promotion programs linked to these populations.

The Research Itinerary of Paulo Freire enables sparking topics of interest to the participants, which were concomitantly revealed to the dialogical process. The methodology entails to encompass the preconceptions established by the group as it progresses, and with this to promote new and productive reflections. This process, characterized in the scope of participatory research, as well as providing opportunities for knowledge exchange, enables participants to become actors of their realities and access new opportunities for action.

This study's contributions are directed to health professionals, especially to nursing, who have strong communication with vulnerable populations, extending to other areas and public policies to reach joint action strategies. Regarding the relevance of Paulo Freire's methodological proposal, it is understood that it was entirely pertinent and timely, since it has made contributions that were still empirical in the course of the meetings, but which certainly materialized as a result of this dialogical and participatory proposal.

It is recommended that other communities in socially vulnerable situations be accompanied and "heard", and that new participatory research be developed in order to approach and promote results which are concomitant to the studied groups, thereby enabling closer approximation of academia with the realities highlighted. 


\section{RESUMO}

Objetivo: Compreender a relação dos determinantes sociais na Promoção da Saúde de mulheres quilombolas. Método: Pesquisa participativa, desenvolvida por meio do Itinerário de Pesquisa de Paulo Freire, que compreende três etapas: investigação temática, codificação e descodificação e desvelamento crítico. Essas etapas foram desenvolvidas nos Círculos de Cultura, de abril a junho de 2016. Foram investigados 20 temas geradores, codificados e descodificados em oito, desvelando a temática mulher e a relação com os Determinantes Sociais. Resultados: Participaram 10 mulheres de uma comunidade quilombola catarinense. Compreenderam-se a Promoção da Saúde desta população e sua interface com os Determinantes Sociais. A saúde, religiosidade, questões raciais, redes sociais e comunitárias emergiram como potencializadoras do empoderamento e fortalecimento comunitário. Conclusão: Percebe-se a acentuada correlação das questões raciais e a fragilidade junto à assistência, à educação e à informação em saúde e, principalmente, o distanciamento de comunidades vulneráveis de uma saúde íntegra e equânime, destacando-se a necessidade eminente de fortalecer estratégias de Promoção da Saúde.

\section{DESCRITORES}

Determinantes Sociais da Saúde; Promoção da Saúde; Mulheres; Grupo com Ancestrais do Continente Africano; Autonomia Pessoal; Enfermagem em Saúde Pública.

\section{RESUMEN}

Objetivo: Comprender la relación de los determinantes sociales en la Promoción de la Salud de mujeres quilombolas. Método: Investigación participativa, desarrollada por medio del Itinerario de Investigación de Paulo Freire, que comprende tres etapas: investigación temática, codificación y desvelamiento crítico. Dichas etapas fueron desarrolladas en los Círculos de Cultura, de abril a junio de 2016. Fueron investigados 20 temas generadores, codificados y descodificados en ocho, develando la temática mujer y la relación con los Determinantes Sociales. Resultados: Participaron 10 mujeres de un comunidad quilombola del Estado de Santa Catarina. Se comprendieron la Promoción de la Salud de esa población y su interfaz con los Determinantes Sociales. La salud, religiosidad, temas raciales, redes sociales y comunitarias surgieron como potencializadores del empoderamiento y fortalecimeinto comunitario. Conclusión: Se nota la acentuada correlación de los temas raciales con la fragilidad en la asistencia, la educación y la información y, especialmente, el alejamiento de comunidades vulnerables de una salud íntegra y ecuánime, destacándose la necesidad eminente de fortalecer estrategas de Promoción de la Salud.

\section{DESCRIPTORES}

Determinantes Sociales de la Salud; Promoción de la Salud; Mujeres: Grupo de Acendencia Continental Africana; Autonomía Personal; Enfermería en Salud Pública.

\section{REFERENCES}

1. Malta DC, Moraes Neto OL, Silva MMA, Rocha D, Castro AM, Reis AAC, et al. National Health Promotion Policy (PNPS): chapters of a journey still under construction. Ciênc Saúde Coletiva [Internet]. 2016 [cited 2018 May 31];21(6):1683-94. Available from: http://www. scielo.br/pdf/csc/v21n6/en_1413-8123-csc-21-06-1683.pdf

2. Teixeira MB, Casanova A, Oliveira CCM, Ensgtrom EM, Bodstein RCA. Avaliação das práticas de promoção da saúde: um olhar das equipes participantes do Programa Nacional de Melhoria do Acesso e da Qualidade da Atenção Básica. Saúde Debate [Internet]. 2014 [citado 2017 nov. 28];38(n.esp.):52-68. Disponível em: http://www.scielo.br/pdf/sdeb/v38nspe/0103-1104-sdeb-38-spe-0052.pdf

3. Heidemann ITSB, Cypriano CC, Gastaldo D, Jackson S, Rocha CG, Fagundes E. Estudo comparativo de práticas de promoção da saúde na atenção primária em Florianópolis, Santa Catarina, Brasil e Toronto, Ontário, Canadá. Cad Saúde Pública [Internet]. 2018 [citado 2018 maio 30];34(4):e00214516. Disponível em: http://www.scielo.br/pdf/csp/v34n4/1678-4464-csp-34-04-e00214516.pdf

4. Albuquerque TIP, Sá RMPF, Araújo Junior JLAC. Perspectivas e desafios da "nova" Política Nacional de Promoção da Saúde: para qual arena política aponta a gestão? Ciênc Saúde Coletiva [Internet]. 2016 [citado 2018 maio 30];21(6):1695-706. Disponível em: http://www. scielo.br/pdf/csc/v21n6/1413-8123-csc-21-06-1695.pdf

5. Jackson SF, Birn AE, Fawcett SB, Poland B, Schultz JA. Synergy for health equity: integrating health promotion and social determinants of health approaches in and beyond the Americas. Rev Panam Salud Pública [Internet]. 2013 [cited 2018 Mar 05];34(6):473-80. Available from: https://www.scielosp.org/scielo.php?script=sci_arttext\&pid=S1020-49892013001200015\&lng=en\&nrm=iso\&tlng=en

6. Gaspar T, Balancho L. Fatores pessoais e sociais que influenciam o bem-estar subjetivo: diferenças ligadas estatuto socioeconômico. Ciênc Saúde Coletiva [Internet]. 2017 [citado 2018 maio 29];22(4):1373-80. Disponível em: http://www.scielo.br/pdf/csc/v22n4/1413-8123csc-22-04-1373.pdf

7. Prestes CRS, Paiva VSF. Psychosocial approach and health of black women: vulnerabilities, rights and resilience. Saude Soc [Internet]. 2016 [cited 2018 May 29];25(3):673-88. Available from: http:/www.scielo.br/pdf/sausoc/v25n3/en_1984-0470-sausoc-25-03-00673.pdf

8. Paula CEA, Silva AP, Bittar Cléria ML. Legislative vulnerability of minority groups. Ciênc Saúde Coletiva [Internet]. 2017 [cited 2018 May 31];22(12):3841-8. Available from: http://www.scielo.br/scielo.php?pid=S1413-81232017021203841\&script=sci_arttext\&tlng=en

9. Leite IB. The Brazilian quilombo: 'race', community and land in space and time. J Peasant Studies. 2015;42(6):1225-40.

10. Cardoso CS, Melo LO, Freitas DA. Condições de saúde nas Comunidades Quilombolas. Rev Enferm UFPE on line [Internet]. 2018 [citado 2018 mar. 05];12(4):1037-45. Disponível em: https://periodicos.ufpe.br/revistas/revistaenfermagem/article/viewFile/110258/28665

11. Heidemann ITSB, Dalmolin IS, Rumor PCF, Cypriano CC, Costa MFBNA, Durand MK. Reflections on Paulo Freire's research itinerary: contributions to health. Texto Contexto Enferm [Internet]. 2017 [cited 2018 May 30];26(4):e0680017. Available from: http://www. scielo.br/pdf/tce/v26n4/en_0104-0707-tce-26-04-e0680017.pdf

12. Rodrigues DMMR, Labegalini CMG, Higarashi IH, Heidemann ITSB, Baldissera VDA. The dialogic educational pathway as a strategy of care with elderly women in sexuality. Esc Anna Nery [Internet]. 2018 [cited 2018 May 30];22(3):e20170388. Available from: http://www. scielo.br/pdf/ean/v22n3/1414-8145-ean-2177-9465-EAN-2017-0388.pdf 
13. Heidemann ITSB, Wosny AM, Boehs A E. Promoção da Saúde na Atenção Básica: estudo baseado no método de Paulo Freire. Ciênc Saúde Coletiva [Internet]. 2014 [citado 2018 maio 31];2014;19(8):3553-9. Disponível em: http://www.scielo.br/pdf/csc/v19n8/1413-8123CsC-19-08-03553.pdf

14. Durand MK, Heidemann ITSB. The promotion of women's autonomy during family health nursing consultations. Rev Esc Enferm USP [Internet]. 2013 [cited 2018 Mar 05];47(2):288-95. Available from: http://www.scielo.br/scielo.php?pid=s0080-62342013000200003\&script=sci_ arttext\&tlng=en

15. Janini JP, Bessler D, Vargas AB. Educação em saúde e promoção da saúde: impacto na qualidade de vida do idoso. Saúde Debate [Internet]. 2015 [citado 2018 maio 29];39(105):480-90. Disponível em: http://www.scielo.br/pdf/sdeb/v39n105/0103-1104-sdeb-39-105-00480.pdf

16. Tavares F. Rediscutindo conceitos na antropologia da saúde: notas sobre os agenciamentos terapêuticos. Mana [Internet]. 2017 [citado 2018 maio 30];23(1):201-28. Disponível em: http://www.scielo.br/pdf/mana/v23n1/1678-4944-mana-23-01-00201.pdf

17. Araújo JA. Racismo, Violência e Direitos Humanos: pontos para o debate. Rev Interdiscip Direitos Humanos [Internet]. 2014 [citado 26 out. 2016];2(2):75-96. Disponível em: http://www2.faac.unesp.br/ridh/index.php/ridh/article/view/177/93

18. Santos RC, Silva MS. Condições de vida e itinerários terapêuticos de quilombolas de Goiás. Saúde Soc [Internet]. 2014 [citado 2019 jan. 11];23(3):1049-63. Disponível em: http://www.scielo.br/scielo.php?script=sci_arttext\&pid=S0104-12902014000301049\&lng=en\&nrm= iso\&tlng=pt

19. Montoro T, Ferreira C. Mulheres negras, religiosidades e protagonismos no cinema brasileiro. Galáxia (São Paulo) [Internet]. 2014 [citado 02 fev. 2017];27(1):145-59. Disponível em: http://www.scielo.br/scielo.php?script=sci_arttext\&pid=S1982-25532014000100012

20. Portella DDA, Araújo EM, Rocha WJSAF, Chaves IM, Oliveira DD. Homicídios dolosos, tráfico de drogas e indicadores sociais em Salvador, Bahia, Brasil. Ciênc Saúde Coletiva [Internet]. 2017 [citado 2018 maio 30]. Disponível em: http://www.cienciaesaudecoletiva.com.br/ artigos/homicidios-dolosos-trafico-de-drogas-e-indicadores-sociais-em-salvador-bahia-brasil/16153

21. Roso A, Romanini M. Empoderamento individual, empoderamento comunitário e conscientização: um ensaio teórico. Psicol Saber Soc. 2014;3(1):83-95.

22. Saldanha MPA, Gonçalves HS. Práticas de empoderamento feminino na América Latina. Rev Estud Soc [Internet]. 2016 [citado 2018 mar. 05];56(1):80-90. Disponível em: http://www.scielo.org.co/pdf/res/n56/n56a07.pdf

23. Pinheiro DGM, Scabar TG, Maeda ST, Fracolli LA, Pelicioni MCF, Chiesa AM. Health promotion competencies: challenges of formation. Saúde Soc [Internet]. 2015 [cited 2018 May 29];24(1):180-8. Available from: http://www.scielo.br/scielo.php?pid=S0104$12902015000100180 \&$ script=sci_arttext\&tlng=en 